\title{
Erratum to: A new flagellated dispersion stage in Paraphysoderma sedebokerense, a pathogen of Haematococcus pluvialis
}

\author{
Martina Strittmatter $^{1} \cdot$ Tiago Guerra $^{2} \cdot$ Joana Silva $^{2}$ - Claire M. M. Gachon ${ }^{1}$
}

Published online: 11 November 2015

(C) Springer Science+Business Media Dordrecht 2015

\section{Erratum to: J Appl Phycol}

DOI 10.1007/s10811-015-0700-8

An incorrect unit was used in the following sentence which is marked in bold. The published version has also been corrected.

Cultures were concentrated by centrifugation and resuspended in $100 \mu \mathrm{L} 3 \mathrm{~N}-\mathrm{BBM}+\mathrm{V}$ medium and Nile red added to a final concentration of $40 \mu \mathrm{g} \mathrm{mL}^{-1}$ from a stock solution of $4 \mu \mathrm{g} \mathrm{mL} \mathrm{m}^{-1}$ dissolved in acetone.

The corrected sentence is now shown below.

Cultures were concentrated by centrifugation and resuspended in $100 \mu \mathrm{L} 3 \mathrm{~N}-\mathrm{BBM}+\mathrm{V}$ medium and Nile red added to a final concentration of $40 \mu \mathrm{g} \mathrm{mL}^{-1}$ from a stock solution of $4 \mathrm{mg} \mathrm{mL}^{-1}$ dissolved in acetone.

The online version of the original article can be found at http://dx.doi.org/ 10.1007/s10811-015-0700-8.

Claire M. M. Gachon

claire.gachon@sams.ac.uk

Scottish Marine Institute, Scottish Association for Marine Science, Oban, Argyll PA37 1QA, UK

2 A4F-Algae For Future SA, Campus do Lumiar-Edifício E-R/C, Estrada do Paço do Lumiar, 1648-038 Lisbon, Portugal 